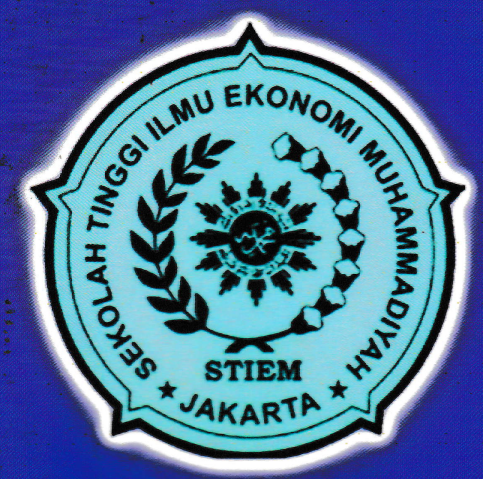

SEKOLAH TINGGI ILMU EKONOMI MUHAMMADIYAH JAKARTA

KAMPUS I:

JI. Kramat Raya

No. 49,

Jakarta Pusat 10450 ,

TIp : (021) 3905357,

Fax. (021) 3927709

KAMPUS II:

JI. Minangkabau

No. 60,

Jakarta Selatan 12970

TIp : (021) 8296108,

Fax. (021) 8296108

website:

www.stiemj.ac.id

email:

stiem_jakt@yahoo.co.id manajemen_s1@stiemj.ac.id
JURNAL

ISSN : 2088-219X
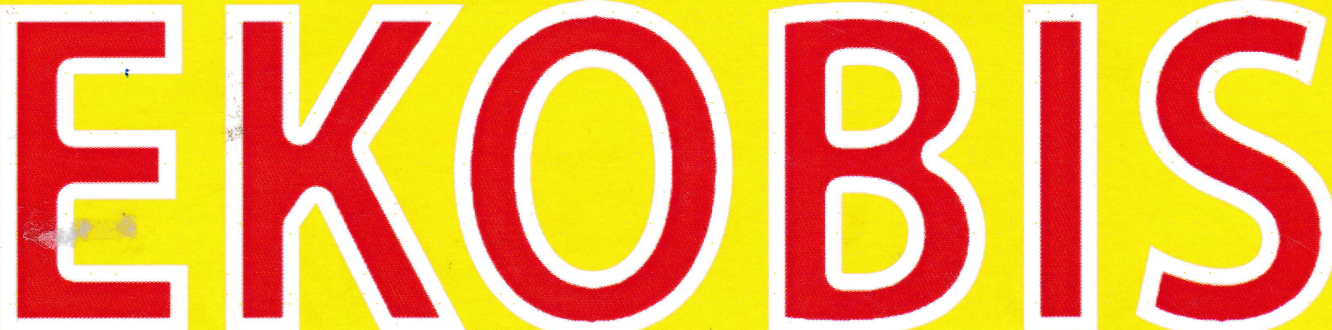

\section{EKONOMI BISNIS \& MANAJEMEN}

Volume I, Nomor 1, MARET 2011

Analisis Strategi Manajemen

PT Asuransi Allianz Life Indonesia Dengan

Menggunakan Metode SWOT

Oleh: Lesmiyanti Muchlis,

STIE Muhammadiyah, Jakarta

- Sistem Pelatihan dan Pengembangan

Sumber Daya Manusia Pada PT Surakarta

Sentosa Sejahtera

Oleh: Noor Indah Rahmawati,

STIE Muhammadiyah Jakarta

- Mengenal Masalah Belajar Sebagai Upaya Meningkatkan Sumber Daya Manusia

Oleh: Pawit Winarto, STIE Kusuma Negara Jakarta

- Pengaruh Kemampuan Kerja Pegawai Terhadap Kualitas Pelayanan Pelanggan Pada Masyarakat Kelurahan Dungus Cariang, Kecamatan Andir, Kodya Bandung, Jawa Barat

Oleh: Pandaya, STIE Muhammadiyah Jakarta

Subali MS, UHAMKA Jakarta

- Pengaruh Penggunaan

Alat Pelindung Diri (APD) Terhadap Produktivitas

Kerja Karyawan Pada PD Purnama, Cikarang

Oleh: Lela Nurlaela Wati,

STIE Muhammadiyah Jakarta

- Pengaruh Pelayanan Jasa Kesehatan

Terhadap Kepuasan Konsumen Pada Klinik

Promedika Health Center

Oleh: M. Nur Rianto AI Arif, UIN Syarif Hidayatullah, Jakarta

Dzurriyatul Awaliyah, STIE Swadaya Jakarta 


\section{SEKOLAH TINGGI ILMU EKONOMI MUHAMMADIYAH JAKARTA}

KAMPUS I:

Jl. Kramat Raya -No: 49.

Jakarta Pusat 10450. TIp : (021) 3905357. Fax. (021) 3927709

\section{KAMPUS II:}

- Jl. Minangkabau No. 60.

Jakarta Selatan 12970 TIp : (021) 8296108 Fax. (021) 8296108

website:

www.stiemj.ac.id

email:

stiem_jakt@yahoo.co.id manajemen_s1@stiemj.ac.id
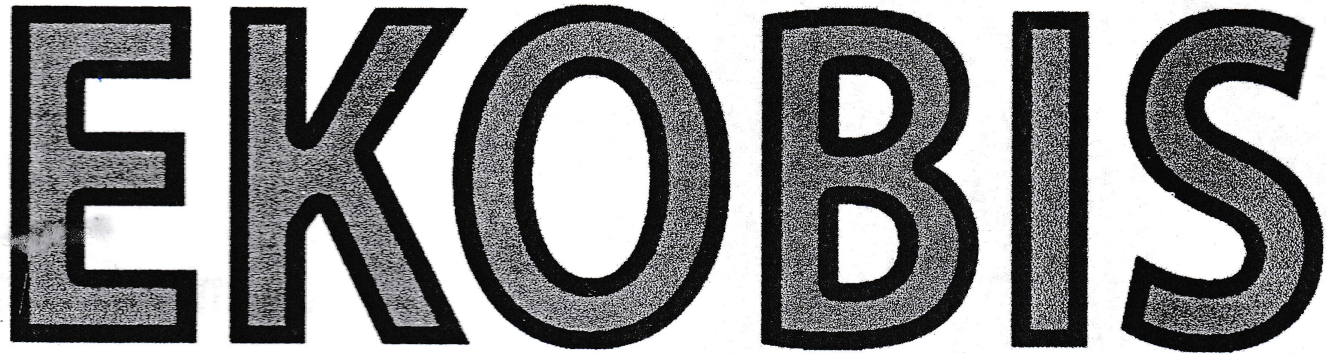

\section{EKONOMI BISNIS \& MANAJEMEN}

Volume I, Nomor 1, MARET 2011

- Analisis Strategi Manajemen

PT Asuransi Allianz Life Indonesia Dengan

Menggunakan Metode SWOT

Oleh: Lesmiyanti Muchlis, STIE Muhammadiyah, Jakarta

- Sistem Pelatihan dan Pengembangan 15 Sumber Daya Manusia Pada PT Surakarta Sentosa Sejahtera

Oleh: Noor Indah Rahmawati,

STIE Muhammadiyah Jakarta

- Mengenal Masalah Belajar Sebagai Upaya Meningkatkan Sumber Daya Manusia

Oleh: Pawit Winarto, STIE Kusuma Negara Jakarta

- Pengaruh Kemampuan Kerja Pegawai Terhadap Kualitas Pelayanan Pelanggan Pada Masyarakat Kelurahan Dungus Cariang, Kecamatan Andir, Kodya Bandung, Jawa Barat

Oleh: Pandaya, STIE Muhammadiyah Jakarta Subali MS, UHAMKA Jakarta

- Pengaruh Penggunaan 37 Alat Pelindung Diri (APD) Terhadap Produktivitas Kerja Karyawan Pada PD Purnama, Cikarang Oleh: Lela Nurlaela Wati,

STIE Muhammadiyah Jakarta

- Pengaruh Pelayanan Jasa Kesehatan 51 Terhadap Kepuasan Konsumen Pada Klinik Promedika Health Center Oleh: M. Nur Rianto AI Arif, UIN Syarif Hidayatullah, Jakarta Dzurriyatul Awaliyah, STIE Swadaya Jakarta 


\title{
SISTEM PELATIHAN DAN PENGEMBANGAN SUMBER DAYA MANUSIA PADA PT SURAKARTA SENTOSA SEJAHTERA
}

Oleh:

Noor Indah Rahmawati; STIE Muhammadiyah Jakarta

\begin{abstract}
The purpose of this research is to identify how the human resources training and development system at PT. Surakarta Sentosa Sejahtera in its efforts to improve company human resources. In compilation of this research, the author conducted field observations in order to obtain comprehensive data or information. Results of this research indicate the human resources training and development system conducted by PT. Surakarta Sentosa Sejahtera has been good enough.
\end{abstract}

Keyword:

Human resources, training and development system

\section{PENDAHULUAN}

Masalah sumber daya manusia merupakan suatu permasalahan yang sering menjadi topik bahasan di kalangan pengusaha yang bergerak di bidang industri. Hal ini karena perubahan teknologi dan bertambahnya ilmu pengetahuan yang sangat cepat. Oleh karena itu, bidang sumber daya manusia (SDM) harus tetap dikembangkan agar nantinya siap menerima masuknya teknologi dan perkembangan ilmu pengetahuan tersebut.

Hampir tidak ada perusahaan yang tidak memperhatikan masalah SDM, apalagi perusahaan dengan tingkat aktivitas produksi yang tinggi dan memiliki banyak karyawan. Dengan besarnya jumlah karyawan yang dimiliki, tentunya makin besar dan bervariasi pula masalah yang dihadapi. Kadangkala karyawan memiliki pandangan dan keinginan yang berbeda dengan perusahaan. Di sinilah peran manajemen SDM dalam mengatasi masalah ketenagakerjaan dalam sebuah perusahaan.

PT Surakarta Sentosa Sejahtera, perusahaan yang bergerak di bidang industri pemintalan benang, berlokasi di Jalan Raya Solo Sragen km 8, Karanganyar, Surakarta. Perusahaan tersebut memerlukan SDM yang berkualitas sebagai salah satu roda penggerak perusahaan. Semakin tingginya tingkat permintaan konsumen yang ditandai dengan dipercayainya PT Surakarta Sentosa Sejahtera sebagai supplier benang tenun dan rajut oleh PT Behaestex, serta dengan adanya perkembangan teknologi mesin pemintalan benang, perusahaan tersebut semakin membutuhkan SDM yang cakap, terampil, serta cekatan untuk menjalankannya. Oleh karena itu, SDM sebagai salah satu sumber daya yang ada perlu ditingkatkan kualitasnya.

Salah satu yang menjadi penunjang dalam peningkatan kualitas SDM adalah kompetensi perusahaan dalam memberikan pelatihan dan pengembangan SDM bagi para karyawan di lingkungan perusahaan tersebut. Perusahaan harus berusaha mewujudkan berbagai bentuk nyata pelatihan, seperti latihan, seminar, kursus keterampilan, dan lain-lain sehingga tanggung jawab yang diberikan pada karyawan dapat dilaksanakan dan tujuan perusahaan akan tercapai dengan tingkat efisiensi dan efektivitas kerja yang baik. Pengembangan SDM akan menciptakan kondisi dinamis di dalam organisasi karena pada dasarnya karyawan yang telah mendapatkan kesempatan tersebut akan lebih mudah menyesuaikan diri terhadap perkembangan teknologi maupun sosial. Untuk itu, usaha yang gigih dalam peningkatan pelatihan SDM sangat diperlukan kehadirannya. Jadi, pelatihan dan pengembangan SDM merupakan faktor penting dalam peningkatan kualitas SDM sehingga SDM yang ada diharapkan dapat menjaga kestabilan dan kelangsungan hidup perusahaan. Kebijaksanaan apa 
pun yang diputuskan perusahaan, jika SDM tidak terampil maka hasilnya kurang memuaskan. Usaha pelatihan dan pengembangan SDM secara dini juga dapat menjaga SDM dari keusangan. Oleh karena itu, penulis mencoba mengadakan penelitian dengan judul "Sistem Pelatihan dan Pengembangan SDM pada PT Surakarta Sentosa Sejahtera".

Berdasarkan latar belakang penelitian, maka identifikasi permasalahannya adalah bagaimana Sistem Pelatihan dan Pengembangan SDM pada PT. Surakarta Sentosa Sejahtera dalam upaya meningkatkan kualitas SDM perusahaan.

Adapun tujuan penelitian ini adalah untuk mengetahui sejauh mana Sistem Pelatihan dan Pengembangan Sumber Daya Manusia sudah dilakukan di PT. Surakarta Sentosa Sejahtera.

\section{TINJAUAN PUSTAKA}

\section{Pengertian Manajemen SDM}

Menurut Edwin B. Flippo (1984): "Manajemen personalia adalah perencanaan, pengorganisasian, pengarahan dan pengendalian atas pengadaan tenaga kerja, pengembangan, kompensasi, integrasi, pemeliharaan, dan pemutus hubungan kerja dengan SDM untuk mencapai sasaran perorangan, organisasi, dan masyarakat".

Menurut Ishak Arep dan Hendri Tanjung (2003): Manejemen SDM adalah ilmu dan seni yang mengatur unsur manusia (cipta, rasa, dan karsa) sebagai aset suatu organisasi dengan cara memperoleh, mengembangkan, dan memelihara tenaga kerja secara efektif dan efisien.

Masing-masing definisi berbeda antara satu sama lain, tetapi pada prinsipnya mempunyai maksud dan tujuan yang sama, yaitu manajemen SDM merupakan suatu proses kegiatan untuk memperoleh data dan menempatkan tenaga kerja yang tepat dalam arti jumlah maupun mutu sehingga tujuan organisasi dapat dicapai secara efektif dan efisien.

\section{Arti Penting Pelatihan dan Pengembangan SDM}

\section{A. Pengertian Pelatihan dan Pengembangan SDM}

Karyawan-karyawan baru jarang melaksanakan pekerjaan secara memuaskan. Mereka harus dilatih menjalankan kewajiban-kewajiban atau tugas-tugas seharusnya mereka kerjakan. Karyawan yang sudah berpengalaman pun mungkin memerlukan pelatihan untuk mengurangi kebiasaan-kebiasaan yang kurang baik atau untuk mempelajari kecakapan baru yang dapat meningkatkan prestasi mereka. Pelatihan tidak hanya berusaha membantu karyawan melaksanakan tugas-tugas mereka, tetapi juga membantu pengembangan tanggung jawab karyawan yang akan datang.

Ada kecenderungan di kalangan masyarakat luas yang menganggap pelatihan sama dengan pengembangan. Perbedaan antara pelatihan dan pengembangan memang sering kabur. Padahal bila dilihat dari berbagai rumusan yang ada, jelas disebutkan perbedaan antara pelatihan dan pengembangan. Untuk lebih jelasnya, penulis menguraikan pendapat yang mendukung, yaitu:

Heidjrachman Ranupandojo dan Suad Husnan (1990): "Pelatihan adalah suatu kegiatan untuk memperbaiki kemampuan kerja seseorang dalam kaitannya dengan aktivitas ekonomi."

Gary Dessler (1997): "Pelatihan merupakan proses mengajarkan karyawan baru atau yang ada sekarang keterampilan dasar yang mereka butuhkan untuk menjalankan pekerjaan mereka."

T. Hani Handoko (2000): "Pelatihan adalah suatu usaha untuk memperbaiki penguasaan berbagai ketrampilan dan teknik pelaksanaan kerja tertentu, terinci, dan rutin."

Moekijat (1995): "Pelatihan adalah mempersiapkan orang-orang melaksanakan jabatan-jabatan mereka sekarang."

Heidjrachman Ranupandojo dan Suad Husnan (1990): "Pengembangan adalah usaha-usaha untuk meningkatkan keterampilan maupun pengetahuan umum bagi karyawan agar pelaksanaan tujuan lebih efisien."

Malayu S. P. Hasibuan (2000): "Pengembangan adalah suatu usaha untuk meningkatkan kemampuan teknis, teoretis, konseptual, dan moral karyawan sesuai dengan kebutuhan pekerjaan atau jabatan melaluli pendidikan dan latihan."

T. Hani Handoko (2000): "Pengembangan adalah setiap usaha untuk memperbaiki pelaksanaan pekerjaan yang sekarang maupun yang akan datang dengan memberikan informasi, mempengaruhi sikapsikap dan menambah kecakapan. Dengan kata lain, pengembangan adalah setiap kegiatan yang dimaksudkan mengubah kelakuan-kelakuan yang terdiri 
dari pengetahuan, kecakapan, dan sikap."

Jadi, jelas dari beberapa rumusan di atas dapat diketahui bahwa pengembangan sangat berbeda dengan latihan. Pengembangan mempunyai makna yang lebih luas dalam upaya memperbaiki dan meningkatkan pengetahuan, keterampilan, sikap, dan sifatsifat kepribadian. Sedangkan latihan sudah tercakup dalam pengembangan.

\section{B. Pentingnya Pelatihan dan Pengembangan Sumber Daya Manusia}

Pelatihan dan pengembangan SDM merupakan usaha perusahaan untuk meningkatkan kualitas para karyawan agar tujuan yang telah ditetapkan dapat tercapai dengan efisien dan efektif. Saat ini pelatihan dan pengembangan dianggap sebagai hal penting untuk mengantisipasi perkembangan ilmu pengetahuan dan teknologi. Oleh karena itu, pelatihan dan pengembangan sangat perlu dilaksanakan sepanjang hidup perusahaan. Penyelenggaraaan pelatihan disesuaikan dengan kebutuhan dari perusahaan itu sendiri.

\section{Manfaat Dan Tujuan Pelatihan Dan Pengembangan Sdm}

Setelah kita mengetahui mengapa pelatihan dan pengembangan sumber daya manusia itu perlu dilakukan di sebuah perusahaan, ada baiknya kita juga mengetahui apa manfaat pelatihan dan pengembangan sumber daya manusia.

Menurut Heidjrachman Ranupandojo dan Suad Husnan (1990), manfaat pelatihan, yaitu:

a. Meningkatkan Produktifitas

b. Memperbaiki Modal

c. Mengurangi Pengawasan

d. Mengurangi kemungkinan terjadinya kecelakaan kerja

e. Meningkatkan kestabilan dan keluwesan organisasi

Sedangkan menurut Edwin B. Flippo (1984), manfaat pengembangan adalah:

a. Bagi perusahaan berupa peningkatan produktivitas, peningkatan moral, pengurangan biaya, dan stabilitas, serta keluwesan (fleksibilitas) organisasi yang semakin besar untuk menyesuaikan diri dengan persyaratan-persyaratan eksternal yang berubah.

b. Bagi perorangan dalam usaha mencari pekerjaan bermakna bagi karier seumur hidup.
Menurut A.A. Anwar Prabu Mangkunegara (2000), manfaat pelatihan dan pengembangan adalah:

a. Meningkatkan penghayatan jiwa dan ideologi

b. Meningkatkan produktifitas kerja

c. Meningkatkan kualitas kerja

d. Meningkatkan ketetapan perencanaan SDM

e. Meningkatkan sikap moral dan semangat kerja

f. Meningkatkan rangsangan agar pegawai mampu berprestasi secara maksimal

g. Meningkatkan kesehatan dan keselamatan kerja

h. Meningkatkan perkembangan pegawai

i. Menghindari keusangan.

Menurut Isjak Arep dan Henri Tanjung (2003), manfaat pelatihan dan pengembangan:

a. Meningkatkan kemampuan profesi para karyawan

b. Meningkatkan semangat dan kegairahan kerja

c. Mengurangi kesalahan dalam bekerja

d. Meningkatkan disiplin kerja

e. Meningkatkan wawasan pengetahuan.

Sedangkan T. Hani Handoko (2000) dalam rumusan lain mengatakan manfaat pelatihan dan pengembangan:

a. untuk menutup "gap" antara kecakapan atau kemampuan karyawan dengan permintaan jaba$\tan$

b. meningkatkan eñisiensi dan efektivitas kerja karyawan dalam mencapai sasaran- sasaran kerja yang telah diterapkan

c. mengurangi perputaran tenaga kerja

d. membuat karyawan lebih produktif

e. membantu karyawan dalam menghindarkan diri dari keusangan

f. melaksanakan pekerjaan dengan lebih baik

\section{Metode-metode Pelatihan dan Pengembangan SDM}

\section{A. Langkah Awal Dalam Pelatihan dan Pengembangan SDM}

Sebagai bagian dari proses pelatihan atau pengembangan, para pakar kepegawaian dan juga para manajer harus menilai kebutuhan, tujuan isi program belajar, dan prinsip belajar. Orang yang bertanggung jawab atas pelatihan dan pengembangan (biasanya seorang pelatih) harus menilai kebutuhan karyawan dan organisasi untuk mempelajari tujuan apa yang perlu diusahakan. Apabila tujuan telah ditentukan, 
isi khusus dan prinsip belajar kemudian dipertimbangkan. Langkah awal yang perlu dilakukan untuk membuat suatu sistem pelatihan dan pengembangan SDM yang efektif, yaitu:
a. Penilaian kebutuhan
b. Tujuan belajar
c. Isi program
d. Prinsip belajar

\section{B. Teknik Pelatihan dan Pengembangan SDM}

Dalam mengkaji teknik-teknik pelatihan dan pengembangan, penting untuk diingat bahwa setiap metode dapat diterapkan, baik terhadap pelatihan maupun pengembangan. Misalnya, suatu kelas untuk teknik-teknik menajemen dapat dihadiri oleh para pengawas dan pekerja yang kemungkinan dipromosikan ke posisi-posisi tersebut. Bagi para pengawas, kelas merupakan pelatihan agar pelaksanaan tugas mereka dapat lebih baik. Bagi para karyawan yang tidak mempunyai tanggung jawab manajemen, kelas dihadiri untuk mengembangkan pegawai-pegawai menjadi pengawas. Instruksi ruang kelas sama bagi kedua kelompok, tetapi mempunyai maksud yang berbeda, pelatihan bagi para pengawas dan pengembangan bagi para pekerja.

Dalam pemilihan teknik yang digunakan dalam program pelatihan dan pengembangan, ada beberapa trade off. Hal ini berarti, tidak ada satu teknik yang selalu paling baik. Metode terbaik tergantung pada sejauh mana suatu teknik memenuhi faktor-faktor berikut:

a. Efektivitas biaya

b. Isi program yang diinginkan

c. Kelayakan fasilitas

d. Preferensi dan kemampuan peserta

e. Preferensi dan kemampuan pelatih

f. Prinsip belajar

Pentingnya enam pilihan ini tergantung pada situasi. Misalnya, keefektifan biaya mungkin bukan merupakan faktor yang penting bila pelatihan seorang pilot dalam perang-perangan darurat. Akan tetapi, metode apa pun yang dipilih, metode ini mempunyai prinsip-prinsip belajar yang berhubungan.

Menurut Edwin B. Flippo (1984) empat metocie dasar dalam pelatihan dan pengembangan, yaitu:

1. Pelatihan di tempat kerja (on the job training)

Karena sebagian besar pekerjaan dalam industri dapat dipelajari dalam jangka waktu yang relatif singkat, metode ini dalah yang paling banyak digunakan.
2. Sekolah vestibule

Merupakan suatu kegiatan khusus manajemen personalia. Sekolah ini biasanya melatih jenis pekerjaan yang sama dengan pelatihan di tempat kerja. Siswa terhindar dari kekacauan dan tekanan situasi kerja sehingga mampu memusatkan perhatian pada pelajaran. Seseorang juga dapat memperoleh tingkat keterampilan tertentu lebih cepat dalam situasi belajar khusus seperti itu.

3. Magang

Sistem pelatihan ketiga, yaitu program magang. Program ini lebih menguntungkan dibandingkan dengan pelatihan di tempat kerja atau sekolah vestibule. Program magang melibatkan pengetahuan dalam melakukan suatu keterampilan atau suatu rangkaian kerja yang berhubungan. Program magang yang biasa menggabungkan pelatihan di tempat kerja dengan pengalaman dari sekolah untuk mata pelajaran tertentu.

4. Kursus-kursus

Sistem pelatihan ini oleh beberapa orang digolongkan dengan pendidikan.

Menurut T. Hani Handoko program-program pelatihan dan pengembangan dirancang untuk meningkatkan prestasi kerja, mengurangi absensi dan perputaran, serta memperbaiki kepuasan kerja. Ada dua kategori pokok program pelatihan dan pengembangan manajemen, yaitu:

1. Metode praktis (on-the job training)

Teknik-teknik on the job training merupakan metode latihan yang paling banyak digunakan. Karyawan dilatih dengan pekerjaan baru melalui supervisi langsung oleh seorang pelatih yang berpengalaman (biasanya karyawan lain). Berbagai macam teknik ini yang biasa digunakan dalam praktik adalah sebagai berikut:
a. Rotasi jabatan
b. Instruksi pekerjaan
c. Magang
d. Coaching
e. Penugasan sementara

2. Metode-metode simulasi dan ieknik-teknik presentasi informasi (Off-the job training)

a. Metode-metode simulasi

(1) Metode studi kasus

(2) Role playing

(3) Business games

(4) Vestibule training

(5) Latihan laboratorium 
(10) Nogram pengembangan eksekutif

b. Teknik-teknik presentasi informasi

(1) kuliah

(2) Presentasi vídeo

(3) Metode konferensi

(4) Programmed instruction

(5) Studi sendiri

\section{Evaluasi Pelatihan \& Pengembangan SDM}

Pelaksanaan pelatihan dan pengembangan menjadi proses perubahan. Karyawan yang tidak terlatih Eubah menjadi karyawan yang cakap, dan karyaman sekarang dapat dikembangkan untuk memikul tanggung jawab baru. Untuk memeriksa suksesnya program, manajer-manajer personalia makin banyak menuntut agar pelatihan dan pengembangan dinilai atau dievaluasi secara sistematis.

Kurang atau tidak adanya evaluasi dapat merupakan lesalahan yang paling besar dalam kebanyakan kegiatan pelatihan dan pengembangan. Pakar-pakar kepegawaian terlalu sering menanyakan "Apakah program mencapai tujuan yang ditentukan untuk itu?". Mereka sening menganggap bahwa program mempunyai nilai karena isinya tampak penting. Atau para pelatih dapat mengandalkan evaluasi para peserta yang mungkin melaporkan betapa menyenangkan pengalaman bagi mereka dibandingkan menilai isinya.

Evaluasi pelatihan dan pengembangan dimulai dengan praujian bagi para peserta. Artinya mereka hames diji untuk memperlihatkan tingkat pengetahuan mereka sebelum program dimulai. Kadang-kadang, ujan seleksi dapat berguna untuk tujuan ini.

Setelah selesai pelatihan atau pengembangan, purnajian (ujian setelah pelatihan) harus menunjulim perbaikan yang mungkin berasal dari program. Rnogram itu dikatakan sukses, apabila perbaikan memenuhi kriteria evaluasi dan dipindahkan ke jhatan. Memindahkan paling baik diukur dengan pelluksanaan jabatan yang meningkat. Studi penyelengearaan berikutnya dapat diadakan beberapa bulan ane behkan beberapa tahun kemudian untuk melihat allah pelajaran itu teiah dikuasai dengan baik.

Ujen setelah pelatihan (purnaujian) tidak menunilen suksesnya pelatihan. Kesuksesan paling baik If diskan oleh perubahan perilaku. Oleh karena in liciteria evaluasi harus dapat dinyatakan dalam meres-syarat perilaku. Ujian setelah pelatihan berwantuk menentukan apakah informasi sudah E tuk pelamar-pelamar yang gagal dalam memahami bahan-bahan. Akan tetapi, suksesnya program ini akhirnya diukur terhadap perubahan perilaku khusus yang terjadi pada pemegang jabatan.

\section{METODOLOGI PENELITIAN}

Metodologi yang penulis gunakan pada penelitian ini menggunakan metode penelitian deskriptif.

Dalam penyusunan penelitian ini, penulis melakukan observasi langsung ke PT. Surakarta Sentosa Sejahtera yang beralamat di Jalan Raya Solo Sragen KM 8, Karanganyar, Surakarta pada tahun 2004.

Dalam observasi langsung ini penulis memperoleh data primer dengan cara mengadakan pengamatan langsung dan melakukan wawancara langsung dengan dengan seseorang yang diberikan wewenang oleh Pemimpin perusahaan.

Sedangkan data sekunder, penulis peroleh dari hasil catatan, laporan jalannya operasi perusahaan dan lain-lain yang ada hubungannya dengan masalah yang diteliti.

Setelah pengumpulan data didapatkan, maka dibuat catatan, rangkuman dan resume dari input (masukan data) lalu diproses untuk selanjutnya dibuatkan output (tampilan data), sehingga akan terlihat hasil akhir yang pada akhirnya dapat dibaca dan dipahami oleh berbagai pihak secara umum.

\section{PEMBAHASAN}

\section{Faktor-faktor yang Berpengaruh terhadap} Sistem Pelatihan dan Pengambangan SDM

PT Surakarta Sentosa Sejahtera merupakan perusahaan industri pemintalan benang yang terdiri dari para tenaga kerja lokal yang bekerja sama dalam mencapai tujuan yang telah ditetapkan. Tujuan tersebut sangat ditentukan oleh kualitas sumber daya manusia, hal ini tidak terlepas dari peran serta menajemen perusahaan yang secara serius memikirkan dan memperhatikan dengan sungguh-sungguh, serta terus berupaya mengoptimalkan faktor kebijakan melalui sistem pelatihan dan pengembangan SDM.

Sumber daya manusia merupakan salah satu aset terpenting dan merupakan roda penggerak bagi kelancaran operasional perusahaan. Melalui sistem pelatihan dan pengembangan SDM diharapkan akan mampu menumbuhkan sikap yang jauh lebih baik 
sehingga tercapai SDM yang berkualitas.

Para tenaga kerja baru biasanya telah mempunyai kecakapan dan keterampilan dasar yang dibutuhkan. Mereka adalah produk dari suatu sistem pendidikan dan mempunyai pengalaman yang diperoleh dari organisasi lain. Tidak jarang pula karyawan baru yang diterima tidak mempunyai kemampuan secara penuh untuk melaksanakan pekerjaan-pekerjaan mereka, bahkan karyawan yang sudah berpengalaman pun perlu belajar dan menyesuaikan diri dengan organisasi beserta kebijakan-kebijakan dan prosedur-prosedur yang diterapkan di organisasi tersebut . Mereka juga mungkin memerlukan latihan dan pengembangan lebih lanjut untuk mengerjakan tugas-tugas secara sukses, mengurangi kebiasaan-kebiasaan kerja yang jelek atau untuk mempelajari keterampilan-keterampilan baru yang akan meningkatkan prestasi kerja mereka. Meskipun usaha-usaha ini memerlukan waktu dan dana, sistem tersebut mampu mengurangi perpindahan karyawan dan mampu membantu karyawan baru menjadi lebih produktif. Investasi ini memberikan keuntungan kepada karyawan maupun perusahaan.

Jumlah tenaga kerja PT Surakarta Sentosa Sejahtera sebanyak 1.025 orang tenaga kerja yang terdiri dari 820 tenaga wanita dan 205 tenaga pria dengan berbagai latar pendidikan, mulai SLTP sampai dengan perguruan tinggi. Jumlah tenaga kerja terbesar adalah tamatan SLTA sebanyak 60\%, disusul SLTP sebanyak 30\%, serta S1 dan D3 sebanyak 10\%. Dari data tersebut, latar belakang yang heterogen seperti umur, pengalaman kerja, dan tingkat pendidikan merupakan salah satu faktor yang berpengaruh terhadap sistem pelatihan dan pengembangan SDM.

\section{Masalah yang dihadapi dalam sistem pelatihan dan pengembangan SDM.}

Perusahaan dapat tumbuh dan berkembang serta dapat meningkatkan produktivitasnya dengan cara memiliki sumber daya manusia yang berkualitas, serta dapat memanfaatkan sumber daya lainnya yang ada di lingkungan perusahaan. Karena perusahaan sangat bergantung pada produk yang dihasilkan, pengendalian operasionalnya sangat dipengaruhi dan ditentukan oleh sumber daya manusia.

Kebijakan yang dilakukan perusahaan dalam usaha meningkatkan kualitas SDM, yaitu dengan memberikan peluang dan menyediakan sarana yang paling tepat dalam menciptakan dan membina tenaga kerja yang berkualitas melalui sistem pelatihan dan pengembangan sumber daya manusia.

Telah dikemukakan sebelumnya bahwa dengan diadakannya latihan dan pengembangan, pekerjaan akan dapat dilaksanakan secara efektif dan efisien. Namun demikian, bisa saja timbul permasalahan dalam pelaksanaanya, permasalahan tersebut misalnya:

1. Hilangnya sebagian waktu yang produktif

Pelatihan dan pengembangan bagi pegawai memerlukan waktu. Sedangkan waktu yang digunakan dalam pelaksanaan pelatihan dan pengembangan ini merupakan waktu yang produktifbagi perusahaan tersebut.

2. Biaya yang mahal

Pelaksanaan sistem pelatihan dan pengembangan SDM memang dibutuhkan oleh perusahaan, tetapi mengingat biaya yang cukup besar, hal ini juga menjadi permasalahan yang perlu diperhatikan.

3. Harapan dari karyawan yang terlalu berlebihan

Dengan latihan tersebut diharapkan terjadinya pengembangan dan perbaikan sikap atau tingkah laku, keterampilan, dan pengetahuan dari karyawan. Mereka yang menerima pelatihan dan pengembangan, mempunyai harapan untuk mendapatkan perbaikan nasibnya, misalnya memperoleh kenaikan gaji atau pangkat melalui promosi.

4. Berpindahnya karyawan yang telah mendapatkan pelatihan dan pengembangan.

Perusahaan telah memberikan perhatian kepada karyawan yang telah mendapatkan pelatihan dan pengembangan. Namun, suatu saat beberapa karyawan yang telah dilatih dan dikembangkan tersebut, bisa saja meninggalkan perusahaan dan mencari perusahaan lain yang mampu memberikan gaji besar. Hal ini berarti kerugian perusahaan secara moral maupun material.

\section{Jalan keluar dalam mengatasi masalah Sistem Pelatihan dan Pengambangan SDM.}

Sarana pendidikan dan latihan atau training-training yang dilakukan oleh perusahaan melalui program sistem pelatihan dan pengembangan sumber daya manusia adalah penting untuk menjamin dan memastikan tersedianya kualitas-kualitas sumber daya manusia (tenaga kerja) dalam perusahaan. Jika para tenaga kerja mendapatkan pendidikan dan pelatihan atau training-training dari perusahaan, diharapkan dapat merealisasikannya ke dalam tugas masing - masing. Hal ini akan berdampak pada perbaikan cara kerja mereka.

Beberapa hal yang perlu diperhatikan untuk mem- 
berikan pelatihan pendidikan atau training-training bagi para tenaga kerja, yaitu sebaiknya dihubungkan dengan analisis dari jabatan para tenaga kerja yang bersangkutan.

Sistem pelatihan dan pengembangan sumber daya manusia yang diterapkan perusahaan akan memberikan kesempatan bagi para karyawan untuk dapat mengembangkan karier dan jenjangnya ke arah yang lebih baik bagi dirinya. Para karyawan akan cenderung lebih efektif dan efisien.

Mengingat begitu pentingnya pelatihan dan pengembangan sumber daya manusia, jalan keluar dari kendala yang dihadapi perusahaan, yaitu:

1. Memanfaatkan waktu yang produktif

Dalam pelaksanaan sistem pelatihan dan pengembangan dibutuhkan waktu yang tepat dalam. Perusahaan tidak memiliki kesibukan yang terlalu banyak, namun untuk pegawai baru terdapat pengecualian mengingat mereka belum mempunyai pengalaman. Pelaksanaan latihan bagi mereka dilaksanakan sebelum ditempatkan.

2. Biaya yang murah

Dalam pelaksanaan sistem pelatihan dan pengembangan, dipilih metode-metode pelatihan dan pengembangan yang mampu mendukung pencapaian sasaran dengan biaya seminimal mungkin.

3. Melaksanakan suplai internal.

Kekosongan jabatan yang ada dipenuhi dari dalam perusahaan.

4. Memperhatikan loyalitas dan dedikasi karyawan yang akan mengikuti pelatihan dan pengembangan.

\section{PENUTUP}

\section{Kesimpulan}

1. Sistem pelatihan dan pengembangan SDM yang dilakukan oleh PT Surakarta Sentosa Sejahtera sudah cukup baik, hal ini terlihat dari kebijakaii perusahaan terhadap karyawan baru, yaitu dengan mengadakan on-the job training selama tiga bulan, dan untuk karyawan yang sudah berpengalaman diadakan retraining secara berkala.

2. Sistem pelatihan dan pengembangan SDM yang dilakukan oleh PT Surakarta Sentosa Sejahtera bertujuan untuk:

a. Mengadakan tugas-tugas secara sukses

b. Mengurangi kebiasaan-kebiasaan kerja buruk c. Untuk mempelajari keterampilan baru

d. Untuk meningkatkan prestasi karyawan

3. Dalam mengatasi masalah-masalah dalam pelaksanaan sistem pelatihan dan pengembangan SDM, PT Surakarta Sentosa Sejahtera telah merencanakan jalan keluar dengan baik untuk mengatasinya.

\section{Saran}

Untuk mengatasi kelemahan-kelemahan yang ada pada perusahaan dalam melakukan sistem pelatihan dan pengembangan SDM, perusahaan perlu melakukan:

1. Penetapan anggaran untuk pelatihan dan pengembangan SDM untuk tiap tahun sehingga diharapkan usaha pelatihan dan pengembangan dapat dilakukan secara rutin dan berkelanjutan, serta melengkapi kelemahan- kelemahan program pengembangan yang terdahulu sehingga pelaksanaannya lebih terkoordinasi.

2. Sebaiknya perusahaan dapat melihat bahwa biaya yang dikeluarkan untuk sistem pelatihan dan pengembangan SDM bukan merupakan kerugian bagi perusahaan melainkan sebagai investasi di masa yang akan datang.

\section{DAFTAR PUSTAKA}

Flippo, Edwin B.. 1984. Manajemen Personalia Jilid I. Edisi Keenam, terjemahan. Jakarta: Penerbit Erlangga.

Gary, Dessler. 1997. Manajemen Sumber Daya Manusia. Terjemahan. Jakarta: PT Prenhalindo.

Handoko, T. Hani, 2000. Manajemen Personalia dan Sumber Daya Manusia. Edisi Kedua. Yogyakarta: BPFE UGM.

Hasibuan, Malayu S.P, 2000. Manajemen Sumber Daya Manusia. Jakarta: Penerbit PT Bumi Aksara.

Ishak, Arep dan Henri Tanjung. 2003. Manajemen Sumber Daya Manusia. Jakarta: Penerbit Universitas Trisakti.

Moekijat. 1995. Manajemen Personalia dan Sumber Daya Manusia, Bandung: Penerbit Mandar Maju.

Mangkunegara, A.A. Anwar Prabu. 2000. Manajemen Sumber Daya Manusia. Bandung: Penerbit Remaja Rosda Karya.

Ranupandojo, Heidjrachman dan Suad Husnan. 1990. Manajemen Personalia. Edisi Keempat. Yogyakarta: BPFE UGM. 